Original Research Article

\title{
Comparative studies on the efficacy of lincomycin and bacitracin for the control of necrotic enteritis in broiler chickens
}

\author{
Ashraf A. Elkomy ${ }^{1}$, Enas Farag², El Shahat I. El Gharbawy², Mohamed Elbadawy ${ }^{1 *}$
}

${ }^{1}$ Department of Pharmacology, Faculty of Veterinary Medicine, Benha University, 13736, Moshtohor, Toukh, Elqaliobiya, Egypt

${ }^{2}$ Department of Pharmacology, Animal Health Research Institute (Benha branch), Benha Egypt

Received: 03 March 2019

Reviewed: 23 March 2019

Accepted: 03 April 2019

\section{*Correspondence to:}

Dr. Mohamed Elbadawy, Email: mohamed.elbadawy@ fvtm.bu.edu.eg

Copyright: (C) the author(s), publisher and licensee Medip Academy. This is an openaccess article distributed under the terms of the Creative Commons Attribution NonCommercial License, which permits unrestricted noncommercial use, distribution, and reproduction in any medium, provided the original work is properly cited.

\begin{abstract}
Background: The present study was conducted to evaluate the efficacy of lincomycin and/or bacitracin for control of experimentally-induced Clostridium perfringens $(\mathrm{CP})$ infection in broiler chickens.

Methods: A total of 100 one-day-old Cobb-mixed chicks were divided into five groups (A, B, C, D and E, each of 20 bird). At the 15th day of age, all birds (except group A) were inoculated orally with CP broth culture $(109 \mathrm{CFU} / \mathrm{mL})$. Two days later, drugs were orally administered once daily for five consecutive days as follow; Group A and B were left untreated. Group C, D, and E were treated with lincomycin $(0.5 \mathrm{~g} / \mathrm{l})$, bacitracin $(100 \mathrm{mg} / \mathrm{l})$, lincomycin and bacitracin, respectively. The efficacy of used drugs was estimated based on clinical symptoms, body weight, weight gain, feed conversion rate. Hematobiochemical changes were also determined.

Results: Necrotic enteritis in broiler chickens induced a significant decrease in body weight, weight gain, erythrocytic count, hemoglobin content, PCV \%, serum proteins, catalase, and superoxide dismutase. Additionally, a marked decrease in serum lipids was obtained. Furthermore, a significant increase in feed conversion rate, leukocytic count, phagocytic activity, phagocytic index, serum total globulin, $\gamma$ globulin and malondialdehyde coupled with a marked increase in $\beta$ and $\alpha$ globulins were determined. Medication of infected broilers with lincomycin and/or bacitracin improved clinical signs and reduced mortality rate to 8,6 and $2 \%$, respectively, as well as restored the performance and hematobiochemical alterations.

Conclusions: a combination of lincomycin and bacitracin was of considerable value for the control of necrotic enteritis in broiler chickens.
\end{abstract}

Keywords: Bacitracin, Broiler chickens, Clostridium perfringens, Lincomycin, Necrotic enteritis

\section{INTRODUCTION}

In Prevention of diseases is a major concern in the poultry industry, due to resulting decreased growth and increased mortality. ${ }^{1}$ Poultry diseases cause severe economic losses to the poultry industry by increasing mortality, reducing weight gain and feed conversion ratio. One of the most important worldwide diseases affecting broiler industry is necrotic enteritis caused by Clostridium perfringens $(\mathrm{CP})$ infection, leading to major economic losses in the poultry industry and severely affecting the performance of birds., ${ }^{2,3}$ Clostridium perfringens (types $\mathrm{A}$ and $\mathrm{C}$ ) found in the intestinal tract of healthy birds can induce NE in broilers flocks. ${ }^{4}$ It is also an enteric bacterial pathogen in humans, poultry, other farm animals and a widespread anaerobic, Gram-positive, spore-forming, non-motile rod. ${ }^{5}$ Lincomycin, belonging to a group of lincosamides, has been in use for the past 40 years. Lincomycin comes from 
actinomycete Streptomyces lincolenensis. ${ }^{6}$ It is a broadspectrum antibiotic indicated in treating serious infections due to susceptible strains of streptococci, pneumococci, and staphylococci. It aids in preventing chronic respiratory disease associated with Mycoplasma and coliform infections in chickens. ${ }^{7}$ Bacitracin is an antibiotic produced by Bacillus licheniformis bacteria in $1945 .{ }^{\circ}$ Bacitracin is a widely used metallopeptide antibiotic produced by Bacillus subtilis and Bacillus licheniformis with a potent bactericidal activity directed primarily against Gram-positive organisms. ${ }^{9}$ Bacitracin is a bactericidal peptide antibiotic which inhibits cell wall synthesis and has additional effects on bacterial membranes. ${ }^{10}$

To our knowledge, there are little data about lincomycin and bacitracin for controlling CL infection in broiler chickens. Therefore, the present study was carried out to evaluate the efficacy of lincomycin and bacitracin either alone or in combination against experimentally-induced $\mathrm{NE}$ in broiler chickens with regard to the hematobiochemical alterations.

\section{METHODS}

\section{Drugs}

Lincomycin hydrochloride and bacitracin methylene disalicylate were obtained from ATCO pharma for pharmaceutical industries, Cairo, Egypt with the commercial name of ATO LINC 400® and BACITOP®, respectively. Each gram powder of ATO LINC 400® includes $453.6 \mathrm{mg}$ lincomycin $\mathrm{Hcl}$ (eq. to $400 \mathrm{mg}$ lincomycin base) and that of BACITOP $®$ contains $62 \mathrm{mg}$ bacitracin methylene disalicylate (eq. to $44.06 \mathrm{mg}$ bacitracin base). It is administered orally at a dose of 100 $\mathrm{mg} / \mathrm{l}$ drinking water for 5-7 days for treatment of $\mathrm{CP}$ infection in broiler chickens.

\section{Experimental chickens}

A total of 100, one-day-old Hubbard mixed breed broiler chicks were bought from a local poultry farm and used in this trial. Birds were kept in wire floor batteries under strict hygienic measures. All chicks were vaccinated with Newcastle vaccines (HitchnerB1 at 7 days and Lasota at 18 days, Intervet International BV Company, Boxmeer, Holland) and Gumboro vaccine (Rhone-Merieau Company, France) at 14 days. The birds were maintained at a suitable temperature and humidity according to their ages. The chickens had free access to water and feed. The feed was free from antibacterial and anticoccidial drugs. The experiments were carried out in accordance with the guidelines set by the Ethical Committee of Faculty of Veterinary Medicine, Benha University, Egypt.

\section{Experimental infection}

Clostridium perfringens type A was kindly obtained from the Department of Microbiology, Animal Health Research
Institute. Dokki, Giza, Egypt. At 15th day of age, chickens in group B, C, D, and E were administered an oral inoculation of $2 \mathrm{ml}$ freshly prepared, $24 \mathrm{~h}$ incubated thioglycolate broth culture of $\mathrm{CP}$ type $\mathrm{C}(1.5 \times 109)$ $\operatorname{organisms} / \mathrm{ml}){ }^{2}$

\section{Experimental design}

At the 17th-day of age (two days of inoculation) where the clinical symptoms of NE were established and reported, drugs were orally (in drinking water) administered once daily for five consecutive days. chickens were divided into 5 equal groups (20 each). Group A (control) was kept noninfected and non-treated; group B one was infected with $\mathrm{CP}$ and not treated. Group $\mathrm{C}$ was infected and treated with lincomycin at $0.5 \mathrm{~g} / \mathrm{l}$; group D infected and treated with $100 \mathrm{mg}$ of bacitracin per liter drinking water and group $\mathrm{E}$ was infected with $\mathrm{CP}$ and treated with lincomycin and bacitracin at the above-mentioned doses.

\section{Blood sampling}

Twenty four h after last administration of drugs, two blood samples from each bird were collected, one sample with EDTA as an anticoagulant for estimation of hematological parameters (erythrocytic count, packed cell volume, hemoglobin content), total leucocytic count, phagocytic activity and phagocytic index. Another sample was used for the estimation of serum total protein, protein fractions using cellulose acetate electrophoresis test, total lipid, cholesterol, triglyceride, superoxide dismutase (SOD), catalase and malondialdehyde (MDA). ${ }^{11-20}$

\section{Statistical analysis}

Data were expressed as mean \pm standard error and were statistically analyzed using according to Petrie and Watson. ${ }^{21}$ Comparison of the mean values was performed and differences were considered statistically significant when $\mathrm{P}<0.05$.

\section{RESULTS}

In the present study, broilers infected with $\mathrm{CP}$ showed clinical signs as depression, ruffled feathers, decreased appetite, diarrhea, dehydration, weight loss, a decrease in weight gain, increased feed conversion rate (Table 1) and the mortality rate was $34 \%$ in the non-treated group (B). The present study revealed that broilers infected with $\mathrm{CP}$ showed significant decreases in the total erythrocytic count, hemoglobin content, Packed Cell Volume \% associated with significant increase leukocytic count, phagocytic activity and phagocytic index all over the experimental period post infection (Table 2). Additionally, the alone treatment of infected broilers by bacitracin or lincomycin in drinking water for 5 successive days showed significant decreases in the erythrocytic count, hemoglobin content, Packed Cell Volume \% associated with significant increase in leukocyte, phagocytic activity $\%$ and phagocytic index at 1st-day post-treatment (Table 
2). However, the combination of bacitracin and lincomycin displayed a non-significant increase in phagocytic activity $\%$ and phagocytic index. Necrotic enteritis in broiler chickens induced a significant decrease in serum total protein, albumin, $\mathrm{A} / \mathrm{G}$ ratio (Table 3), catalase and SOD (Table 4). Additionally, non-significant decrease in total lipid, cholesterol, triglyceride levels was recorded (Table 4). Furthermore, a significant increase in feed conversion rate, leukocytic count, phagocytic activity, phagocytic index, serum total globulin, $\gamma$ globulin and MDA coupled with a non-significant increase in globulin and $\alpha$ globulin were determined. Medication of infected broilers with lincomycin and bacitracin either alone or in combination showed improved clinical signs as they were healthy and viable as well as decreased mortality rate up to 8,6 and $2 \%$ in group $\mathrm{C}, \mathrm{D}$, and $\mathrm{E}$, respectively.

\section{DISCUSSION}

Although several clinical cases of NE have been reported in poultry industry, including broilers raised on floor, cagereared layers, commercial layers either raised in cages or in floor pens, ${ }^{22,23}$ there is a significant lack of data in literature about the clinical efficacy of antimicrobials and their combinations for control of NE in broiler chickens. The current study was conducted to check the efficacy of lincomycin and bacitracin against experimentally induced $\mathrm{NE}$ in broiler chickens.

Table 1: Effect of lincomycin $(0.5 \mathrm{~g} / \mathrm{l})$ and bacitracin $(100 \mathrm{mg} / \mathrm{l})$ in drinking water for 5 successive days on body performance in chickens infected with $\mathrm{CP}$ at 1st, and 10th-day post-treatment. Values are Mean $\pm \mathrm{SE}(\mathrm{n}=5)$.

\begin{tabular}{|c|c|c|c|c|c|c|c|c|c|}
\hline \multirow[b]{2}{*}{ Group } & \multicolumn{3}{|c|}{$15^{\text {th }}$ day of age } & \multicolumn{3}{|c|}{$\mathbf{1}^{\text {st-day post-treatment }}$} & \multicolumn{3}{|c|}{$10^{\text {th }}$-day post-treatment } \\
\hline & $\begin{array}{l}\text { Bodyweight } \\
\text { (g) }\end{array}$ & $\begin{array}{l}\text { Weight } \\
\text { gain }(\mathrm{g})\end{array}$ & FCR & Bodyweight (g) & $\begin{array}{l}\text { Weight gain } \\
\text { (g) }\end{array}$ & FCR & Bodyweight (g) & $\begin{array}{l}\text { Weight gain } \\
(\mathrm{g})\end{array}$ & FCR \\
\hline Control & $499.6 \pm 9.36$ & $461.1 \pm 13.3$ & 1.25 & $1284.5 \pm 14.6$ & $784.9 \pm 19.43$ & 1.25 & $2079.2 \pm 16.3$ & $794.7 \pm 13.9$ & 1.65 \\
\hline $\begin{array}{l}\text { Infected } \\
\text { non- } \\
\text { treated }\end{array}$ & $504.3 \pm 5.89$ & $465.8 \pm 12.8$ & 1.25 & $1089.4 \pm 27.7 * * *$ & $585.1 \pm 15.8 * * *$ & 1.55 & $1874.5 \pm 23.6^{* * *}$ & $697.9 \pm 14.4 * * *$ & 1.83 \\
\hline $\begin{array}{l}\text { Infected } \\
\text { lincomyci } \\
\text { n-treated }\end{array}$ & $498.8 \pm 17.8$ & $460.3 \pm 12.6$ & 1.25 & $1132.3 \pm 24.7 * *$ & $633.5 \pm 20.9 * *$ & 1.49 & $1912.5 \pm 24.5 * *$ & $780.2 \pm 9.10$ & 1.66 \\
\hline $\begin{array}{l}\text { Infected } \\
\text { bacitracin- } \\
\text { treated }\end{array}$ & $500.7 \pm 18.9$ & $462.0 \pm 13.1$ & 1.25 & $1139.3 \pm 21.8^{* *}$ & $638.6 \pm 18.8 * *$ & 1.49 & $1920.5 \pm 24.8^{* *}$ & $781.1 \pm 8.20$ & 1.66 \\
\hline $\begin{array}{l}\text { Infected } \\
\text { lincomyci } \\
\text { n- and } \\
\text { bacitracin- } \\
\text { treated }\end{array}$ & $502.7 \pm 15.9$ & $464.4 \pm 13.1$ & 1.25 & $1144.2 \pm 22.9 * *$ & $641.5 \pm 20.9 * *$ & 1.48 & $1936.8 \pm 28.9 * *$ & $792.6 \pm 9.37$ & 1.64 \\
\hline
\end{tabular}

FCR: Feed conversion rate, **Significant at $\mathrm{P}<0.01 \quad * * *$ Significant at $\mathrm{P}<0.001$

Table 2: Effect of lincomycin $(0.5 \mathrm{~g} / \mathrm{l})$ and bacitracin $(100 \mathrm{mg} / \mathrm{l})$ in drinking water for 5 successive days on erythrogram, leukocytic count, phagocytosis and phagocytic index in chickens infected with CP at 1st-day posttreatment. Values are Mean $\pm \operatorname{SE}(n=5)$.

\begin{tabular}{|c|c|c|c|c|c|c|}
\hline Group & $\begin{array}{l}\text { RBCs } \\
\left(10^{6} / \mu l\right)\end{array}$ & $\mathrm{Hb}(\mathrm{gm} / \mathrm{dl})$ & $\operatorname{PCV}(\%)$ & $\begin{array}{l}\text { Total WBCs } \\
\left(\times 10^{3} / \mu \mathrm{l}\right)\end{array}$ & Phagocytosis & $\begin{array}{l}\text { Phagocytic } \\
\text { index }\end{array}$ \\
\hline Control & $3.75 \pm 0.33$ & $10.74 \pm 0.93$ & $31.46 \pm 0.84$ & $10.86 \pm 0.33$ & $62.67 \pm 0.54$ & $4.74 \pm 0.38$ \\
\hline $\begin{array}{l}\text { infected non- } \\
\text { treated }\end{array}$ & $2.08 \pm 0.24 * *$ & $7.75 \pm 0.54 * *$ & $26.98 \pm 0.58 * *$ & $12.96 \pm 0.39 * *$ & $65.21 \pm 0.29 * *$ & $5.79 \pm 0.18 *$ \\
\hline $\begin{array}{l}\text { Infected } \\
\text { lincomycin- } \\
\text { treated }\end{array}$ & $2.66 \pm 0.25 *$ & $8.60 \pm 0.20 *$ & $28.17 \pm 0.76^{*}$ & $11.90 \pm 0.14 *$ & $64.03 \pm 0.12 *$ & $5.63 \pm 0.11 *$ \\
\hline $\begin{array}{l}\text { Infected } \\
\text { bacitracin- } \\
\text { treated }\end{array}$ & $2.69 \pm 0.13^{*}$ & $8.54 \pm 0.14 *$ & $28.31 \pm 0.73 *$ & $11.92 \pm 0.18^{*}$ & $64.15 \pm 0.21 *$ & $5.64 \pm 0.12 *$ \\
\hline $\begin{array}{l}\text { Infected- } \\
\text { lincomycin } \\
\text { and bacitracin } \\
\text { treated }\end{array}$ & $3.59 \pm 0.19$ & $9.96 \pm 0.68$ & $30.20 \pm 0.38$ & $10.91 \pm 0.52$ & $62.71 \pm 0.33$ & $4.75 \pm 0.23$ \\
\hline
\end{tabular}


Table 3: Effects of lincomycin $(0.5 \mathrm{~g} / \mathrm{l})$ and bacitracin $(100 \mathrm{mg} / \mathrm{l})$ in drinking water for 5 successive days on serum levels of total protein, albumin and globulin fraction in chickens infected with $\mathrm{CP}$ at 1st-day post-treatment. Values are Mean \pm SE $(n=5)$.

\begin{tabular}{|c|c|c|c|c|c|c|c|}
\hline Group & T. P & Alb & Globulin ( & $\mathbf{l} / \mathrm{dl})$ & & & \\
\hline & & & $\alpha$ & $\beta$ & $\gamma$ & Total & A/G ratio \\
\hline Control & $5.41 \pm 0.21$ & $3.20 \pm 0.21$ & $0.64 \pm 0.10$ & $0.69 \pm 0.18$ & $0.88 \pm 0.16$ & $2.21 \pm 0.21$ & $1.45 \pm 0.12$ \\
\hline Infected non-treated & $4.55 \pm 0.10 * *$ & $2.18 \pm 0.18 * *$ & $0.68 \pm 0.17$ & $0.70 \pm 0.13$ & $0.99 \pm 0.23$ & $2.37 \pm 0.17$ & $1.08 \pm 0.11$ \\
\hline $\begin{array}{l}\text { Infected } \\
\text { lincomycin-treated }\end{array}$ & $4.69 \pm 0.17 *$ & $2.44 \pm 0.14 *$ & $0.66 \pm 0.18$ & $0.71 \pm 0.18$ & $0.89 \pm 0.22$ & $2.25 \pm 0.13$ & $1.08 \pm 0.11$ \\
\hline $\begin{array}{l}\text { Infected bacitracin- } \\
\text { treated }\end{array}$ & $4.75 \pm 0.21 *$ & $2.55 \pm 0.18 *$ & $0.65 \pm 0.18$ & $0.70 \pm 0.16$ & $0.89 \pm 0.24$ & $2.22 \pm 0.11$ & $1.16 \pm 0.13$ \\
\hline $\begin{array}{l}\text { Infected } \\
\text { lincomycin- and } \\
\text { bacitracin- treated }\end{array}$ & $5.28 \pm 0.18$ & $3.08 \pm 0.22$ & $0.63 \pm 0.16$ & $0.70 \pm 0.18$ & $0.88 \pm 0.21$ & $2.21 \pm 0.16$ & $1.40 \pm 0.16$ \\
\hline
\end{tabular}

Table 4: Effects of lincomycin $(0.5 \mathrm{~g} / \mathrm{l})$ and bacitracin $(100 \mathrm{mg} / \mathrm{l})$ in drinking water for 5 successive days on lipid profile and levels of catalase, SOD and MDA in chickens infected with CP at 1st-day post-treatment. Values are Mean \pm SE $(n=5)$.

\begin{tabular}{|c|c|c|c|c|c|c|}
\hline \multirow[t]{2}{*}{ Group } & \multicolumn{3}{|c|}{ lipid profile (mg/dl) } & \multicolumn{2}{|c|}{$\begin{array}{l}\text { Antioxidants enzyme } \\
\text { (U/mL) }\end{array}$} & \multirow{2}{*}{$\begin{array}{l}\text { MDA } \\
\mathrm{mmol} / \mathrm{ml}\end{array}$} \\
\hline & T. lipid & cholesterol & Triglyceride & Cat & SOD & \\
\hline Control & $226.3 \pm 1.87$ & $93.6 \pm 1.94$ & $114.1 \pm 1.82$ & $37.1 \pm 1.42$ & $256.31 \pm 1.49$ & $22.24 \pm 0.39$ \\
\hline Infected non-treated & $224.9 \pm 2.94$ & $92.0 \pm 1.90$ & $113.9 \pm 1.93$ & $43.4 \pm 1.42 * *$ & $250.12 \pm 1.15 * *$ & $31.41 \pm 1.15 * *$ \\
\hline $\begin{array}{l}\text { Infected lincomycin- } \\
\text { treated }\end{array}$ & $226.0 \pm 2.85$ & $93.4 \pm 1.69$ & $114.0 \pm 1.87$ & $37.02 \pm 1.09 *$ & $252.09 \pm 1.01 *$ & $37.76 \pm 1.20$ \\
\hline Infected bacitracin-treated & $225.7 \pm 2.93$ & $93.4 \pm 1.67$ & $113.9 \pm 1.55$ & $37.4 \pm 1.03 *$ & $252.03 \pm 1.16^{*}$ & $37.36 \pm 1.37$ \\
\hline $\begin{array}{l}\text { Infected lincomycin- and } \\
\text { bacitracin- treated }\end{array}$ & $226.0 \pm 2.55$ & $93.6 \pm 1.45$ & $113.9 \pm 1.72$ & $37.6 \pm 1.34$ & $253.33 \pm 1.89$ & $37.88 \pm 1.53$ \\
\hline
\end{tabular}

*Significant at $\mathrm{P}<0.05 \quad$ ** Significant at $\mathrm{P}<0.01$

The experimental birds were divided into five equal groups, each of 20 bird. After 24-36 h of CP infection, the chickens of infected groups $(\mathrm{B}, \mathrm{C}, \mathrm{D}$, and $\mathrm{E})$ developed clinical symptoms of NE. The recorded clinical symptoms are similar to those recorded previuosly.,3 Reduction in weight gain in broiler chickens infected with $\mathrm{CP}$ was recorded before. ${ }^{24}$ Typical clinical signs and reduction of body weight due to $\mathrm{NE}$ were also recorded in broiler chickens suffering from NE. ${ }^{2,3}$ Our results are reinforced by results reported that bacitracin abolished the development of $\mathrm{NE}$ and reduced the mortality rate and suppressed the bacterial growth and feed efficiency associated with $\mathrm{NE}$ in broilers. ${ }^{25}$ In the same way, the treatment of broilers infected with $\mathrm{CP}$ using lincomycin showed improved body performance. ${ }^{26}$ Moreover, CP isolated from chicken layer flocks in Germany was sensitive to lincomycin. ${ }^{27}$ Furthermore, the reduction of mortality rate beside the disappearance of clinical signs and improved body gain in broiler chickens treated with lincomycin were reported. ${ }^{28}$

The phagocytosis recorded in the present study after $\mathrm{CP}$ inoculation was also recorded previously and same changes in blood picture of the chickens in the current study were reported previously, ${ }^{3,29}$ and stated that broilers suffering from NE showed a significant decrease in the total erythrocytic count, hemoglobin content, Packed Cell Volume \% associated with significant increase leukocytic count, phagocytic activity and phagocytic index all over the experimental period post infection. Similarly, in ducklings suffering from NE, the same alterations in blood picture were reported previously. ${ }^{30}$ Furthermore, in turkey poults, $\mathrm{CP}$ showed a decrease in the total erythrocytic count, hemoglobin content and PCV\%. ${ }^{31}$ Treatment of infected $\mathrm{CP}$-infected broilers chickens with lincomycin has completely stopped the development of $\mathrm{NE}$ and improved the erythrocytic count, hemoglobin content, packed cell volume $\%$ and leukocytic count. ${ }^{28}$ Also, zinc bacitracin improved hematological parameters, phagocytosis $\%$ and phagocytic index in broilers suffered from NE. ${ }^{32}$ Also, in turkey, zinc bacitracin showed good efficacy against clostridial infection and improved the hematological values. ${ }^{33}$ Moreover, in rabbits, zinc bacitracin induced improvements in erythrogram and leukogram in rabbits after CP infection. ${ }^{34}$

The reduction of plasma protein in infected chickens suffering from NE may be due to liver damage caused by 
clostridial toxins, thus impaired the synthesis of albumin. ${ }^{35}$ Previously, in broiler chickens, NE induced a significant reduction in protein and albumin coupled with an increase in total globulin and globulin fractions, $\alpha, \square$ and $\gamma$ globulin. ${ }^{36}$

In the present study, treatment of infected chickens with bacitracin and/or lincomycin restored the plasma protein alterations. Same results were recorded by Engberg et al., and Hofacre et al. They found that zinc bacitracin significantly reduced the number of $\mathrm{CP}$ in broiler chickens and improved the total protein, albumin and globulin. ${ }^{37}$ Such finding was compatible with those reported previously where $\mathrm{CP}$ isolated from broilers is sensitive to bacitracin and improved protein picture. ${ }^{38}$

Infected broilers with $\mathrm{CP}$ showed non-significant decrease in total lipid, cholesterol and triglyceride levels throughout the experimental period after infection, while treatment of infected broilers by bacitracin and/or lincomycin restored the lipid profile compared with control broilers. Similar results were recorded previously in broilers $^{39}$ and in turkeys ${ }^{40}$ suffering from NE.

The results of this study revealed that broiler chickens infected with CL showed a significant reduction in catalase and SOD together with a significant increase in MDA level. Treatment infected boilers by bacitracin and/or lincomycin induced improvements in catalase, SOD activities and serum MDA levels. Infected broilers with $\mathrm{CP}$ resulted in weakening the antioxidant defense mechanism as evidenced by decreases in SOD and catalase associated with an elevation in MDA. ${ }^{39}$

It could be concluded that the combination of lincomycin and bacitracin at the tested doses was of considerable value for the control of NE in broiler chickens than using them separately.

Funding: No funding sources Conflict of interest: None declared

Ethical approval: The experiments were carried out in accordance with the guidelines set by the Ethical Committee of Faculty of Veterinary Medicine, Benha University, Egypt

\section{REFERENCES}

1. Porter RE, Jr. Bacterial enteritides of poultry. Poult Sci. 1998;77(8):1159-65.

2. Elbadawy M, Aboubakr M. Efficacy of colimox ${ }^{\circledR}$ (a new combination of amoxicillin and colistin) in the control of experimentally induced necrotic enteritis in broiler chickens. Int $\mathbf{J}$ Pharmacol Toxicol. 2017;5(1):51-6.

3. Aboubakr M, Elbadawy M. Efficacy of Flagymox ${ }^{\circledR}$ (Amoxicillin and Metronidazole Combination) in Controlling Clostridium perfringens infection in Broiler Chickens. World J Pharm Pharmac Sciences. 2016;6(1):80-95.
4. Grass JE, Gould LH, Mahon BE. Epidemiology of foodborne disease outbreaks caused by Clostridium perfringens, United States, 1998-2010. Foodborne Pathog Dis. 2013;10(2):131-6.

5. Uzal FA, Vidal JE, McClane BA, Gurjar AA. Clostridium Perfringens Toxins Involved in Mammalian Veterinary Diseases. Open Toxinol J. 2010;2:24-42.

6. Dollery C. Spectinomycin. In: Dollery C, Boobis AR, eds. Therapeutic Drugs. 2nd ed. Edinburgh; London [etc.]: Churchill Livingstone; 1999:78-80.

7. Swayne DE, Glisson JR, Nair VL. Diseases of Poultry. 13 ed. USA: John Wiley \& Sons, Inc; 2013.

8. Hofacre CL, Froyman R, George B, Goodwin MA, Brown J. Use of Aviguard, Virginiamycin, or Bacitracin MD Against Clostridium perfringensAssociated Necrotizing Enteritis. J Appl Poult Res.1998;7(4):412-8.

9. Russell JB, Strobel HJ. Effects of additives on in vitro ruminal fermentation: a comparison of monensin and bacitracin, another gram-positive antibiotic. J Anim Sci. 1988;66(2):552-8.

10. Butaye P, Devriese LA, Haesebrouck F. Antimicrobial growth promoters used in animal feed: effects of less well known antibiotics on gram-positive bacteria. Clin Microbiol Rev. 2003;16(2):175-88.

11. Weiss DJ, Wardrop KJ. Schalm's veterinary hematology. 6th Ed. Philadelphia, U.S.A: Blackwell Publishing Ltd; 2010.

12. Lee LF, Bacon LD. Ontogeny and line differences in the mitogenic response of chicken lymphocytes. Poult Sci. 1983;62(4):579-84.

13. Doumas BT, Bayse DD, Carter RJ, Peters T, Jr., Schaffer R. A candidate reference method for determination of total protein in serum. I. Development and validation. Clin Chem. 1981;27(10):1642-50.

14. Henry RJ, Winkelman JW, Cannon DC. Clinical Chemistry: Principles and Techniques. 2nd ed: Happer and Row Publishers, New York; 1974.

15. Frings CS, Dunn RT. A colorimetric method for determination of total serum lipids based on the sulfophospho-vanillin reaction. Am J Clin Pathol. 1970;53(1):89-91.

16. White WL, Erickson MM, Stevens SC. determination of cholesterol. In: White WL, Erickson MM, Stevens SC, eds. Chemistry for medical technologists. 3rd ed. Saint Louis, USA: Saint Louis: C. V. Mosby Co.; 1970.

17. Bergmeyer HU. Methods of Enzymatic Analysis V2. 2nd ed: Academic Press; 1974.

18. Nishikimi M, Appaji N, Yagi K. The occurrence of superoxide anion in the reaction of reduced phenazine methosulfate and molecular oxygen. Biochem Biophys Res Commun. 1972;46(2):849-54.

19. Sinha AK. Colorimetric assay of catalase. Anal Biochem. 1972;47(2):389-94.

20. Nielsen F, Mikkelsen BB, Nielsen JB, Andersen HR, Grandjean P. Plasma malondialdehyde as biomarker 
for oxidative stress: reference interval and effects of life-style factors. Clin Chem. 1997;43(7):1209-14.

21. Petrie A, Watson P. Statistics for Veterinary and Animal Science. 3rd ed. United Kingdom.: WileyBlackwell (John Wiley \& Sons, Ltd); 2013.

22. Tsai SS, Tung MC. An outbreak of necrotic enteritis in broiler chickens. Journal of Chinease Society of Veterinary Science. 1981;7:13-7.

23. Dhillon AS, Roy P, Lauerman L, et al. High mortality in egg layers as a result of necrotic enteritis. Avian dis. 2004;48(3):675-80.

24. Abo-Zaid O. Efficacy of Kitassmycin and Amoxicillin on Chlosteridial Infections in Broiler Chickens. Master Thesis, Department of Pharmacology, Faculty of Veterinary Medicine, Zagazig University, Egypt; 2017.

25. Brennan J, Skinner J, Barnum DA, Wilson J. The efficacy of bacitracin methylene disalicylate when fed in combination with narasin in the management of necrotic enteritis in broiler chickens. Poult Sci. 2003;82(3):360-3.

26. Abdalla O, Emam E. Compatibility of Diclazuril and Lincomycin in Broiler Chickens. Zag Vet J. 2006;33(2):147-61.

27. Gad W, Hauck R, Krueger M, Hafez H. In vitro determination of antibiotic sensitivities of Clostridium perfringens isolates from layer flocks in Germany. Arch Geflügelk. 2012;76(4):S234-8.

28. Mohamed AGA. Concurrent uses of diclazuril and lincomycin for controlling of severe necrotic enteritis in broiler chicks. Master Thesis, Department of Pharmacology, Faculty of Veterinary Medicine, Zagazig University, Egypt; 2016.

29. Salah H, Masour ES, Reham R, El Hamid ESA. Study on the Effect of Humic Acid on Growth Performance, Immunological, Some Blood Parameters and Control Intestinal Closterdium in Broiler Chickens. Zag Vet J. 2015;43(1):102-9.

30. Allam H, Dina M, Abdullaha S, Nahad G. Immunobiochemical and Pathological Studies on Necrotic Enteritis in Pekin Duckling with Trail of Treatment. Mansoura Vet Med J. 2013;12(2):45-53.

31. Tork D, Kalaba Z, Mostafa Y, Zayed M. Growth performance and hematological parameters of turkey poults as affected by efeective microorganisms. J Animal and Poultry Prod. 2016;7(1):15-22.
32. Adel A. Some Pharmacological Studies on Synbiotics and Phytobiotics. PhD Thesis, Department of Pharmacology, Faculty of Veterinary Medicine, Zagazig University, Egypt; 2018.

33. Sims MD, Dawson KA, Newman KE, Spring P, Hoogell DM. Effects of dietary mannan oligosaccharide, bacitracin methylene disalicylate, or both on the live performance and intestinal microbiology of turkeys. Poult Sci. 2004;83(7):114854.

34. Agnoletti F, Bacchin C, Bano L, Passera A, Favretti M, Mazzolini E. Antimicrobial susceptibility to zinc bacitracin of Clostridium perfringens of rabbit origin. World Rabbit Sci. 2007;15(1):19-22.

35. Doxey DL. Clinical pathology and diagnostic procedures. 2nd. ed. London.: Bailliere Tindall; 1983.

36. Abdel Ziz SA, Abdel Motaal SMA, Abd-Allah OE, Sarhan MMI. Concurrent use of ciprofloxacin and metronidazole for controlling of some bacterial infections in broiler chickens. Benha Veterinary Medical Journal. 2016.

37. Engberg RM, Hedemann MS, Leser TD, Jensen BB. Effect of zinc bacitracin and salinomycin on intestinal microflora and performance of broilers. Poult Sci. 2000;79(9):1311-19.

38. Slavic D, Boerlin P, Fabri M. Antimicrobial susceptibility of Clostridium perfringens isolates of bovine, chicken, porcine, and turkey origin from Ontario. Can J Vet Res. 2011;75(2):89-97.

39. Wang H, Ni X, Liu L, Zeng D, Lai J, Qing X. et al. Controlling of growth performance, lipid deposits and fatty acid composition of chicken meat through a probiotic, Lactobacillus johnsonii during subclinical Clostridium perfringens infection. Lipids Health Dis. 2017;16(1):38.

40. Gazdzinski P, Julian RJ. Necrotic enteritis in turkeys. Avian Dis. 1992;36(3):792-98.

Cite this article as: Elkomy AA, Farag E, Shahat I, Gharbawy EL, Elbadawy M. Comparative studies on the efficacy of lincomycin and bacitracin for the control of necrotic enteritis in broiler chickens. Int $\mathbf{J}$ Basic Clin Pharmacol 2019;8:1153-8. 